chicks as their own and were supplying them with food. On June 3, my last visit, all three chicks were seen perched in a single tree $15 \mathrm{~m}$ from the nest and were capable of flying well.

My two concerns when adding these chicks to this nest were that the adults would kill the new birds immediately or that the adults would not feed the new chicks. In this case, the adoption was apparently successful. Great Horned Owls appear to readily adopt chicks that are similar in size to their own, provided that the total number does not exceed a normal clutch. This technique is an effective way of dealing with orphaned owls. Ideally, the orphan(s) should be younger than the original chick(s), so as not to affect the chance of survival of the original $\operatorname{chick}(\mathrm{s})$.

\section{Acknowledgments}

Thanks to Stuart Houston for his advice and helpful comments on this manuscript. Also thanks to Doug Kemp for his watchful eye and passion for these owls, and to Elizabeth Travis for her help in the field.

\title{
SWAINSON'S HAWK RESPONSE TO FIRE AT LAST MOUNTAIN LAKE NATIONAL WILDLIFE AREA, SK
}

PHILIP S. TAYLOR, Canadian Wildlife Service, 115 Perimeter Road, Saskatoon SK, S7N OX4

The Canadian Wildlife Service has conducted over 50 prescribed burns at Last Mountain Lake National Wildlife Area (LMLNWA), beginning in 1980 , to manage the native grasslands and improve habitat for migratory birds and other wildlife. Our observations of diurnal raptors responding to fire are very similar to the experiences at Lostwood National Wildlife Refuge, ND. ${ }^{1}$

Our burns are most frequently done in late March to early June, less frequently in mid-August to early November, and range in size from under one hectare to over 280 ha. Raptors normally arrive at LMLNWA at different times: Ferruginous Hawk and Northern Harrier in late March or early April; Red-tailed Hawk in early to midApril; and Swainson's Hawk in mid- to late April. Abundance of these raptors during the breeding season at LMLNWA varies between years but the averages in recent years are Ferruginous Hawk (0-1 pair), Redtailed Hawk (<5 pair) and Swainson's Hawk (15-30+ pair). Northern Harrier are a common nesting species but no quantitative data are available. ${ }^{2}$ LMLNWA is near the northern limit of the breeding range of Swainson's and Ferruginous hawks, approximately $340 \mathrm{~km}$ north of Lostwood National Wildlife Refuge. Therefore, hawks present in our area are most likely to be summer breeding residents, rather than migrants.

Swainson's Hawks, when present at LMLNWA, arrive at large prescribed burns soon after the fire is started and often within the first 30 minutes. Hawk numbers observed are lower than at Lostwood National Wildlife Refuge, usually between 1 and 6 individuals at any one time. During a burn in the second week of April 1992, two Swainson's Hawks arrived on site, 


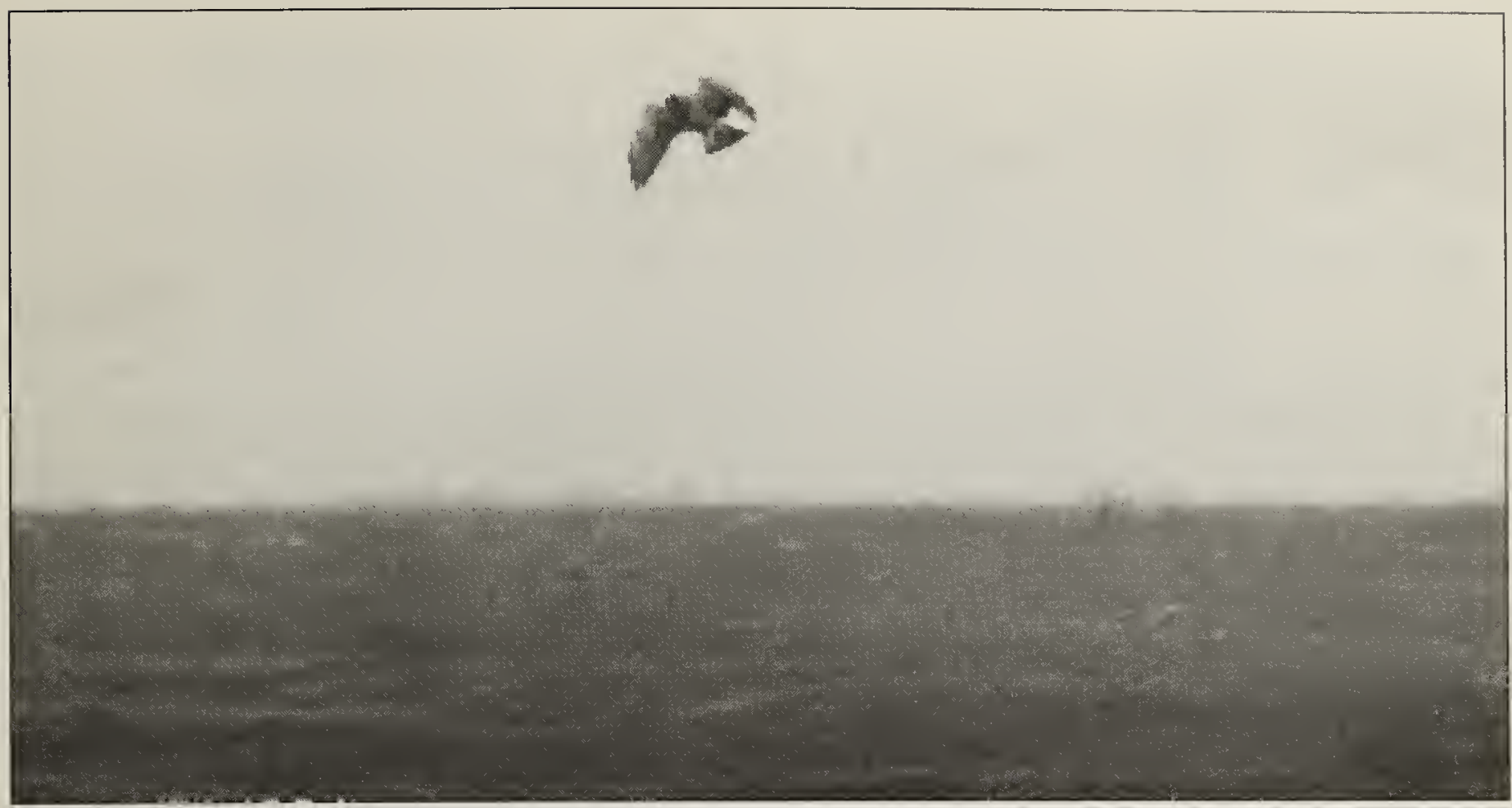

Swainson's Hawk hunting over burned grassland at Last Mountain Lake National Wildlife Area

P.S. Taylor

making them the first arrivals for that year. Swainson's Hawks actively hunt around the fire front, using the thermals created by the fire to maneuver over the burned and unburned grassland, dropping down to catch small rodents. They do not appear to avoid smoke rising from the fire, but instead use the upward moving heated air to gain altitude. Once present at a burn, one or more Swainson's Hawks are frequently, and often continually, in evidence. After the fire burns out, the hawks are seen perched on the ground with distended crops, or running and hopping over the burned prairie in the act of catching rodents amongst the ashes.

We have not observed Ferruginous Hawks hunting near fires while we conducted our prescribed burns. We have observed single Red-tailed Hawks come near to active fires on a few occasions, and they may have hunted over the burned grassland, but if so, it was infrequent and did not occur throughout the entire fire event. One or two Northern Harriers were observed at many fires, particularly those adjacent to marsh habitats, however, the harriers did not stay in the immediate burn area for any length of time and did not increase in numbers during the burn event.

The behaviour of Swainson's Hawks around prescribed fires at LMLNWA has led us to conclude that they are the most fire adapted species of diurnal raptor breeding in the area. Their attendance at a burn is predictable and expected. Because fire has largely been eliminated from the remaining grasslands of the Canadian prairies, today Swainson's Hawks have less opportunity to use their adaptation to take advantage of fire while foraging, except in special sites like Last Mountain Lake National Wildlife Area and Lostwood National Wildlife Refuge, where these historically natural disturbances have been reintroduced to the ecosystem.

1. MURPHY, R. K. and K. A. SMITH. 2007. Swainson's Hawks gather to forage at fires on a northern prairie. Blue Jay 65(2):78-81.

2. TAYLOR, A. 2000. Raptor nest survey 2000 on the Last Mountain Lake National Wildlife Area with historic review. Unpublished report: S-29. Canadian Wildlife Service, Last Mountain Lake National Wildlife Area. 30 pp. 